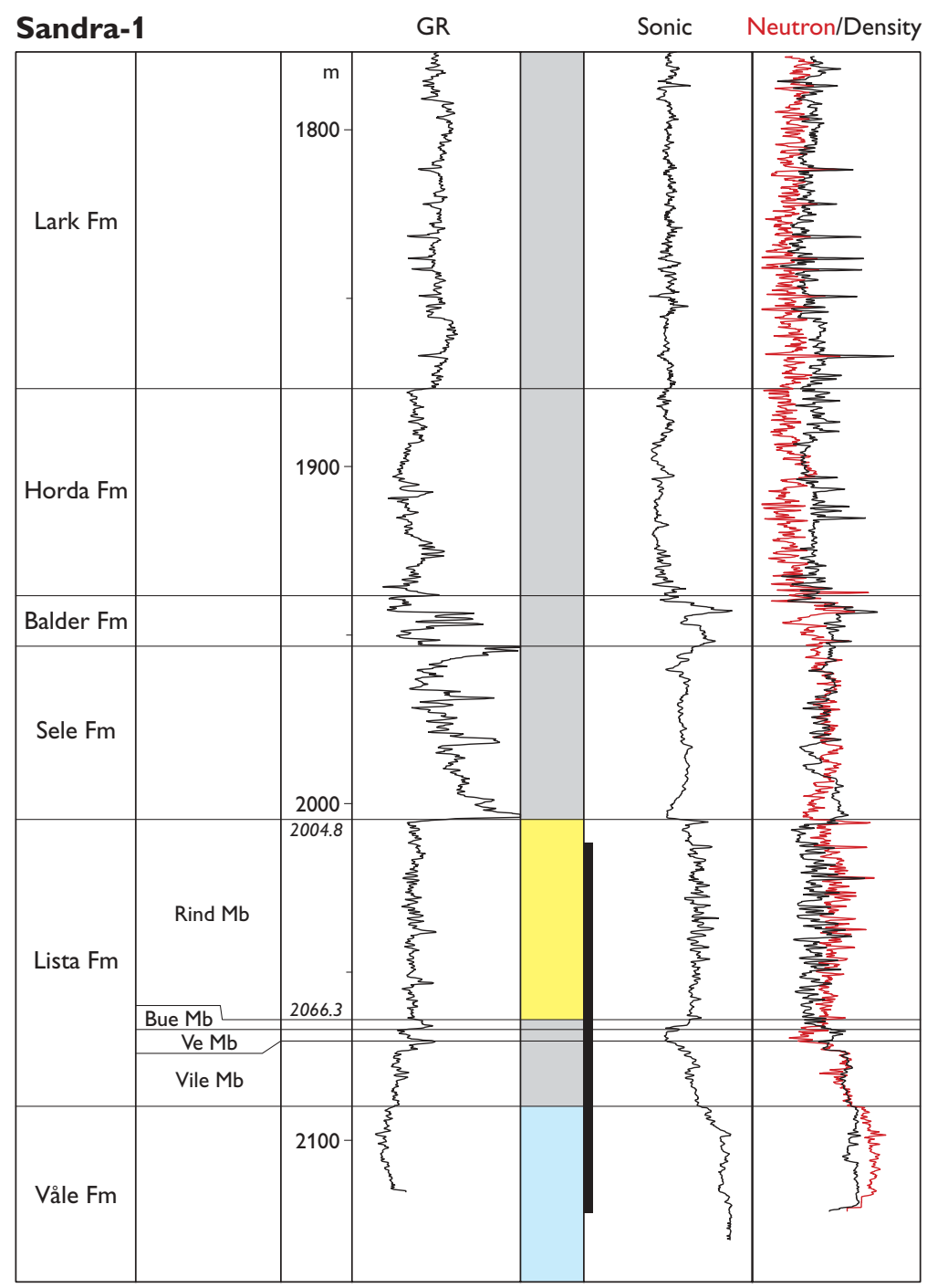

Fig. 33. Sandra-1, reference well for the Rind Member. Black bar shows cored section.

sharp and characterised by prominent shifts on both the sonic and density logs (Figs 29, 33). It is often difficult to identify the boundaries on the gamma-ray log alone.

Depositional environment. Although the sandstones of the Rind Member were deposited from highly concentrated gravity flows, their present appearance largely records postdepositional liquefaction and fluidisation processes.

Age. Thanetian.

Correlation. The Rind Member may be contemporaneous with parts of the lithologically dissimilar Østerrende Clay encountered in the Storebælt region (Fig. 1), with sandstones in the higher parts of the Heimdal Formation (Hardt et al. 1989) and with the Upper Balmoral Sandstone of the Mey Sandstone Member of Knox \& Holloway (1992). However, the Rind Member is not contiguous with those sandstone units and has a different source area.

\section{Sele Formation}

History. The Sele Formation was established by Deegan \& Scull (1977) for the dark grey to greenish grey, laminated and carbonaceous, tuffaceous, montmorillonite-rich shales and siltstones that overlie the non-laminated and nontuffaceous shales of the Lista Formation in some areas, or arenaceous sediments belonging to a variety of different units in other areas. The original definition of the Sele boundary is followed herein. This implies that the base of the Sele Formation is located at the base of the "laminated tuffaceous shales" that overlie the "non-laminated, nontuffaceous shales" of the Lista Formation (Deegan \& Scull 1977; see Boundaries section under the Lista Formation for further details). Sandstones occur in the Sele Formation in the Danish sector; these are established as a new member, the Kolga Member.

Type well. British sector well 21/10-1,2131-2100 m MDKB. 
Danish reference wells. Siri-1, 2072.6-2047.5 m MDKB

(Fig. 14; Plates 1, 4); Tabita-1, 2958.8-2941.4 m MDKB (Fig. 34; Plate 2).

Distribution and thickness. The Sele Formation is recognised from a large number of North Sea wells and it has a basinwide distribution. In the Danish sector, the thickness varies from 5 to $54 \mathrm{~m}$ (Fig. 35).

Lithology. The Sele Formation consists of medium to dark grey, brownish or black laminated mudstones. Thin tuff layers occur in the upper part of the formation. It contains three or more well-laminated intervals where dark mudstone beds alternate with lighter coloured mudstone beds. The well-laminated intervals are enriched in organic material resulting in a high gamma-ray response, primarily due to increased uranium content. The most organic-rich, and often darkest, most well-laminated interval is found in the basal part of the formation (Fig. 36). The mudstones of the Sele Formation show an overall upward increase in the silt fraction. In the upper half of the formation, the mudstones may be interbedded with thin, very fine-grained sandstone laminae and thin sandstone beds (Fig. 37). The sandstone beds are up to $12 \mathrm{~cm}$ thick, normally graded and display parallel lamination. Locally, and dominantly in the upper part of the formation, graded tuff laminae less than $1 \mathrm{~cm}$ thick are present. In cores, the tuff laminae have a light purple colour. Small calcite concretions are present, but rare. In the Siri Canyon, the Sele Formation is interbedded with sandstones or it grades upwards into a succession of thinly interbedded sandstones and mudstones. Thin sandstone intrusions occur, but only in the lower part of the formation.

Log characteristics. The Sele Formation is characterised by high gamma-ray readings throughout, with a number of gamma-ray peaks. On the gamma-ray log, the base of the Sele Formation is generally marked by a conspicuous upward shift to consistently higher gamma-ray readings than those of the underlying Bue Member (Figs 38, 39). In most wells, a pronounced gamma-ray peak follows a short distance above the base of the Sele Formation (e.g. Augusta-1 and E-8; Fig. 38). In wells to the north and west of the Danish sector, the stratigraphic distance between the shift to higher gamma-ray readings at the base of the Sele Formation and the gamma-ray peak is considerably greater (e.g. in the Norwegian well 2/7-1; Fig. 25). In some wells in the Danish sector (and in most Siri Canyon wells), the basal high gamma-ray interval is missing and the base of the Sele Formation is marked by the pronounced gamma-ray peak (e.g. Cleo-1 and Nini-3; Figs 38, 39).

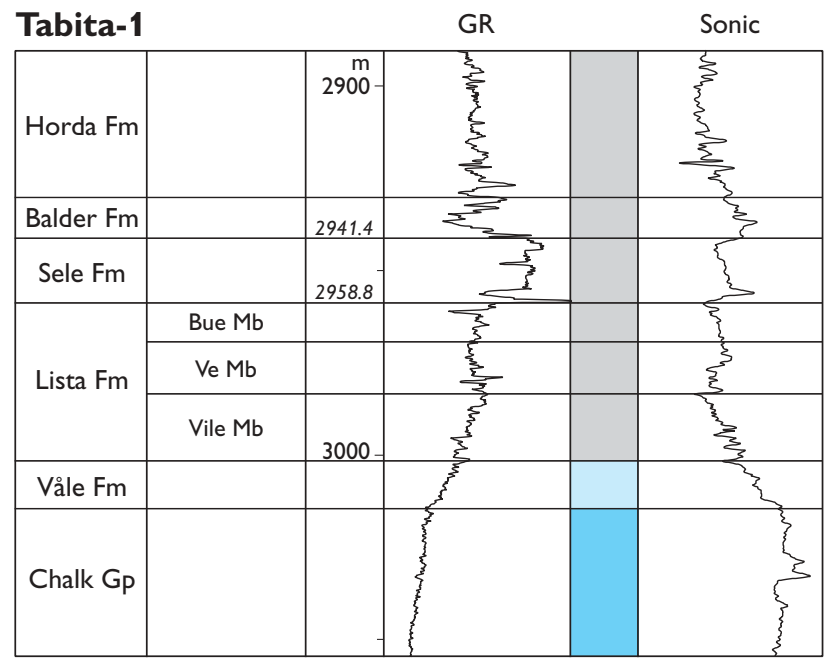

Fig. 34. Tabita-1, Danish reference well for the Sele Formation.

Boundaries. The lower boundary is characterised by a change from the light to dark grey and greyish black mudstones with thin sandstone laminae of the Bue Member (Lista Formation), to dark grey to black well-laminated mudstones without sandstone laminae of the Sele Formation (Fig. 36). The upper boundary is at the base of the Balder Formation.

Subdivision. Knox \& Holloway (1992) suggested an informal threefold subdivision of the Sele Formation based

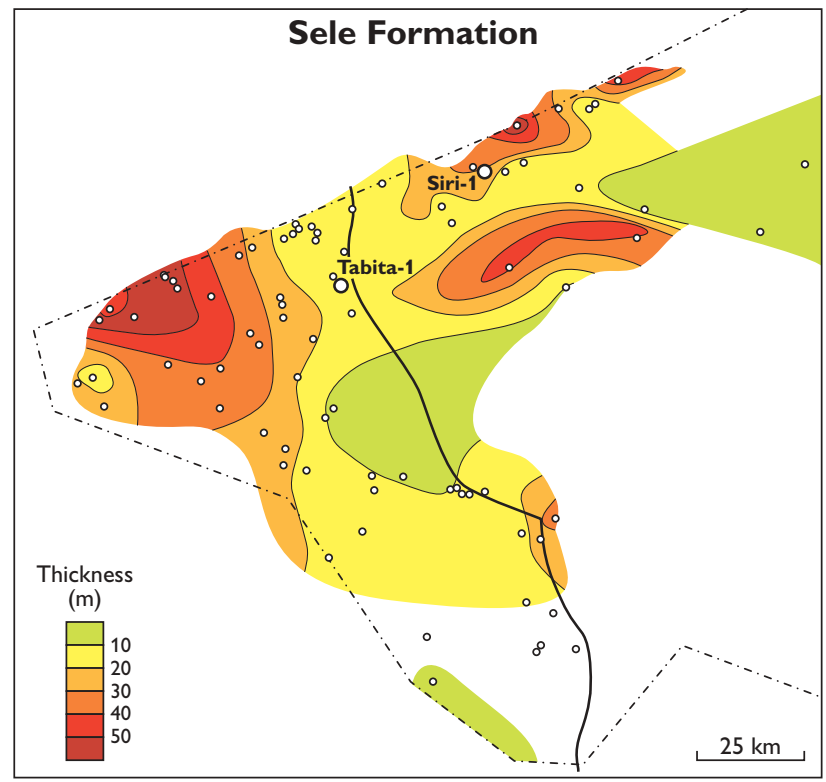

Fig. 35. Isochore map of the Sele Formation in the study area. The positions of the two Danish reference wells, Siri-1 and Tabita-1, are indicated in the figure. 


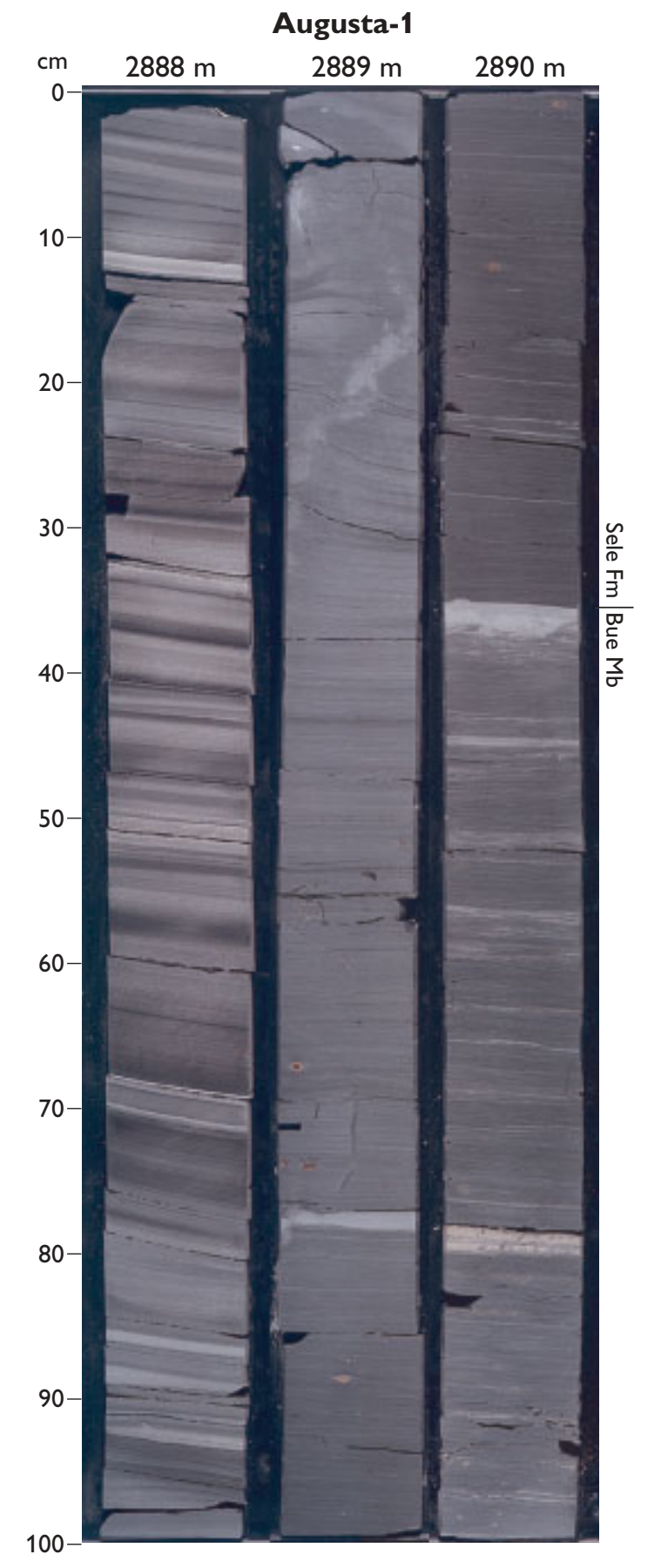

Fig. 36. Core photographs of the Lista-Sele formation boundary interval in the Augusta- 1 well. The upper part of the Bue Member (Lista Formation) consists of mudstones with thin sand- and siltstone laminae superficially resembling mudstone-in-mudstone lamination. At $2890.35 \mathrm{~m}$, the Bue Member is overlain sharply by the laminated mudstones of the Sele Formation. Depths are core depths.

on the gamma-ray log signature. This subdivision can also be recognised on petrophysical logs from most wells in the Danish sector (the subdivision is shown in five wells in Figs 24, 26 and 38), whereas other lithological changes are more subtle. The subdivision is outlined below.

\section{Unit S1}

This unit comprises a lower subdivision S1a and an overlying subdivision S1b. Subdivision S1a is identical to the Bue Member of the Lista Formation and the stratigraphic interval from the base of the Sele Formation (sensu Deegan \& Scull 1977) up to the base of the lowermost conspicuous gamma-ray peak within that formation (Fig. 38). That peak is associated with relatively low sonic values. Subdivision S1b has its base at the gamma-ray peak and its top at the base of the next gamma-ray peak. The gamma-ray response decreases up through S1b. Unit $S 1$ consists of brownish grey to dark grey and black, well-laminated mudstones.

\section{Unit S2}

The base of the unit is at the base of the second gamma-ray peak. This peak can be differentiated from the gamma-ray peak at the base of $S 1 b$ by its association with high sonic values. Unit S2 can be divided into a lower subdivision (S2a) characterised by a relatively high gamma-ray response level and an overlying subdivision (S2b) with a lower gamma-ray response (Fig. 38). The two subdivisions are separated by a gammaray low. Unit S2 consists of light grey to brownish dark grey, laminated to well-laminated mudstones. Both the lamination and the colour of the two subdivisions are very similar in the cores encountered in this study and it is almost impossible to distinguish the two subdivisions on lithology alone. Knox \& Holloway (1992) observed tuff layers in the basal part of unit S2b in the British wells; tuffs were not observed in the Danish wells..

\section{Unit S3}

This unit is characterised by high and increasingupwards gamma-ray values. The base of the unit is defined by a sharp increase in gamma-ray readings (Fig. 38). There is no significant colour difference between the mudstones of units S2 and S3 in the Danish wells, but lamination seems to be better developed in unit S3 than in unit S2. Tuff layers were observed in unit S3 in the British wells studied by Knox \& Holloway (1992). Similar tuff layers have been observed in wells from the Siri Canyon, and may further be used to distinguish unit $\mathrm{S} 3$ from the upper part of unit $\mathrm{S} 2$. 
The Sele Formation includes a sandstone unit (Kolga Member, new) in the Danish North Sea sector.

Macro- and ichnofossils. Fish scales and skeletal fragments are common in cores from the Sele Formation. Bioturbation is very rare, but Chondrites ispp. has been observed locally.

Microfossils and palynomorphs. Benthic foraminifers are rare in the Sele Formation. The LO of an acme of the dinoflagellate genus Apectodinium and the coeval LO of the shortranged $A$. augustum mark a level at, or a few centimetres above the base of the Sele Formation. The HO of $A$. augustum is located in the lower part of the Sele Formation. The $\mathrm{HO}$ of an influx of the dinoflagellate Cerodinium wardenense marks a level in the upper part of the Sele Formation. The $\mathrm{HO}$ of an influx of the diatoms Fenestrella antiqua and Coscinodiscus morsianus is located in the uppermost part of the Sele Formation. Throughout, the formation contains abundant spores and pollen, in particular pollen of the genus Inaperturopollenites.

Depositional environment. The mudstones of the Sele Formation represent a mixture of pelagic fallout and dilute, low-density mud turbidites. The well-laminated character of the sediment, the high content of organic material and uranium, and the general lack of trace fossils and benthic foraminifers indicate starved sedimentation under dysoxic to anoxic bottom conditions. Common diatoms indicate a high nutrient level in the water mass.

The tuffs of the Sele Formation are evidence of extensive volcanism in the region. The significant depauperation of the benthic microfaunas during the deposition of the Sele Formation was most likely caused by isolation of the North Sea Basin (Schmitz et al. 1996). The restriction and isolation of the basin was the result of a sea-level fall, possibly combined with (or caused by) tectonic uplift to the north-west (Knox et al. 1981). Based on microfossils, the palaeoenvironment has been suggested to represent an upper bathyal setting with a palaeodepth estimate of around $300 \mathrm{~m}$ (Mitlehner 1996). The palynomorph assemblage indicates a marine environment characterised by a massive influx of terrestrial palynomorphs.

Age. Sparnacian (sensu Aubry et al. 2003) - early Ypresian, with the lowermost level possibly of Thanetian age.

Correlation. The Sele Formation corresponds to the Haslund Member of the Ølst Formation (Heilmann-Clausen et al. 1985). Its upper part correlates with the Haslund Member-equivalent diatomitic Knudeklint Member of the

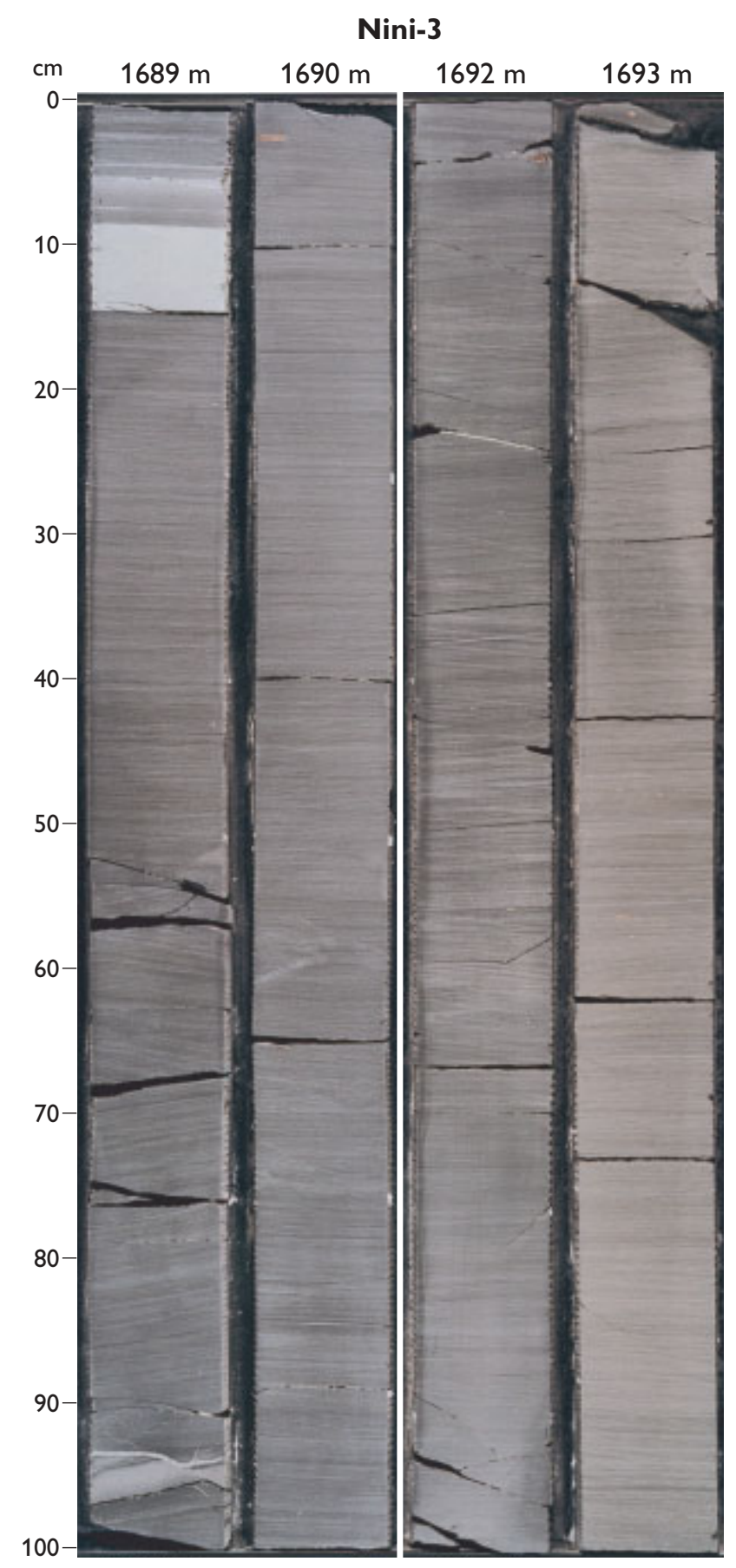

Fig. 37. Core photographs from the Nini-3 well showing the upper, arenaceous part of the Sele Formation. The interval belongs to the S2a subunit of the Sele Formation (see text for further explanation). Stratigraphic position of the figured interval is shown in Fig. 39. Depths are core depths.

Fur Formation in north-west Jylland (Danielsen \& Thomsen 1997). The lower boundary of the Sele Formation correlates with the boundary between the Østerrende Clay and the Haslund Member onshore Denmark. 


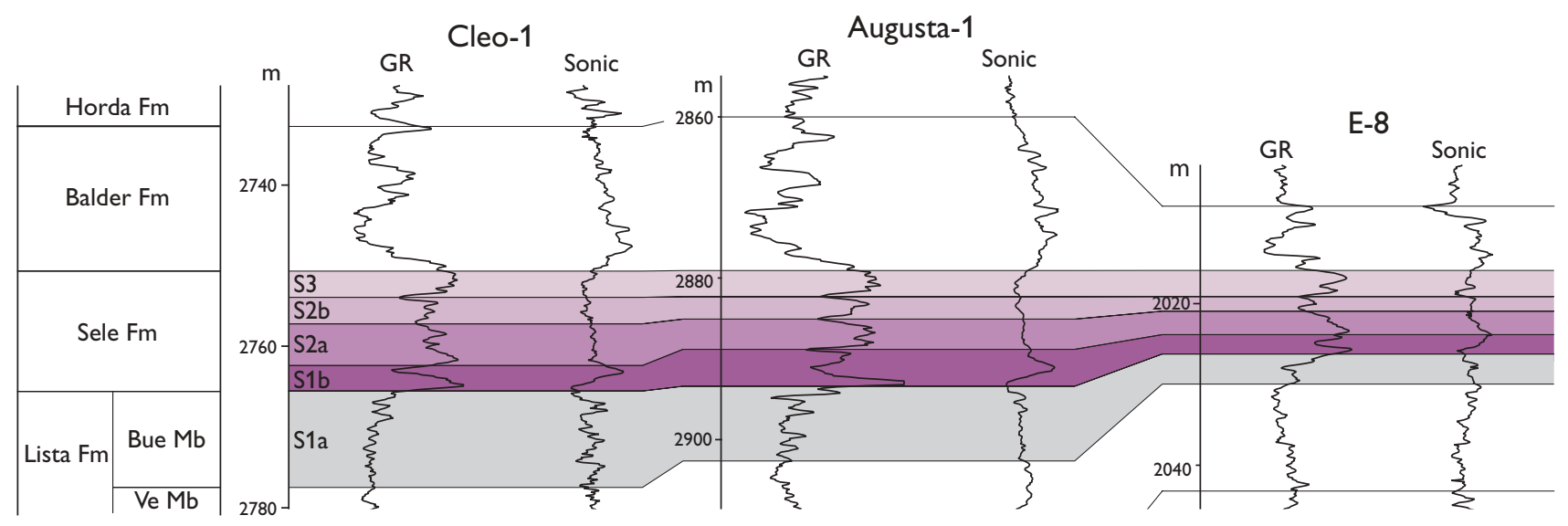

Fig. 38. Correlation diagram of the Sele Formation showing the Sele units S1-3 of Knox \& Holloway (1992).

The lower part of the Sele Formation, consisting of laminated, dark grey to black mudstones, correlates with the lithologically very similar, $15 \mathrm{~m}$ thick informal unit Stolle Klint Clay that constitutes the lower part of the Haslund Member, onshore Denmark (Heilmann-Clausen 1995). This unit is known from throughout the North Sea (Hardt et al. 1989; Knox \& Holloway 1992) and constitutes most or all of the Sele S1b unit of Knox \& Holloway (1992).

\section{Kolga Member}

new member

History. The Kolga Member consists of sandstone deposits within the Sele Formation. These sandstones were previously recognised by a stratigraphic working group at Statoil Norway in the mid-1990s and were informally referred to the Hermod Formation of Hardt et al. (1989).

Derivation of name. After the goddess Kolga.

Type well. Danish sector well Siri-3, 2066.4-2036.1 m MDRT (Fig. 24; Plate 4).

Reference well. Danish sector well Nini-3, 1717.2-1700.4 m MDRT (Figs 26, 39; Plate 4).
Distribution and thickness. The Kolga Member has a restricted distribution in the Siri Canyon in the northern part of the Danish sector (Fig. 20c). It reaches a thickness of up to $30 \mathrm{~m}$.

Lithology. The member consists primarily of fine-grained to very fine-grained, olive-green to greenish grey, well-sorted, quartz-rich sandstones (Fig. 39). Rounded and translucent quartz grains dominate the mineralogical assemblage, but the content of glaucony grains is high (15$25 \%$ ). Mica and small pyrite concretions are present in small amounts. Locally, the sandstones are partly cemented by calcite and chlorite. The member usually includes one thick unit composed of amalgamated sandstone beds and a number of thinner sandstone beds interbedded with mudstones that are lithologically comparable to the Sele Formation mudstones described above.

Log characteristics. The Kolga Member is clearly defined on the gamma-ray log by a blocky pattern with intermediate values. This pattern differs from the high gamma-ray readings that normally characterise the lower Sele Formation. The Kolga Member may show a gradual upward decrease in gamma-ray response in its lower part (e.g. in the well Nini-3; Figs 26, 39). However, this does not reflect grain-size change, judging from core examination. The density log shows a blocky pattern with low density 
Fig. 39. Core log of the sandstonedominated Kolga Member encased in the Sele Formation mudstones in the Nini-3 well. For legend, see Fig. 9. Intervals marked by grey bars in the core depth column are shown as core photos in Fig. 37.

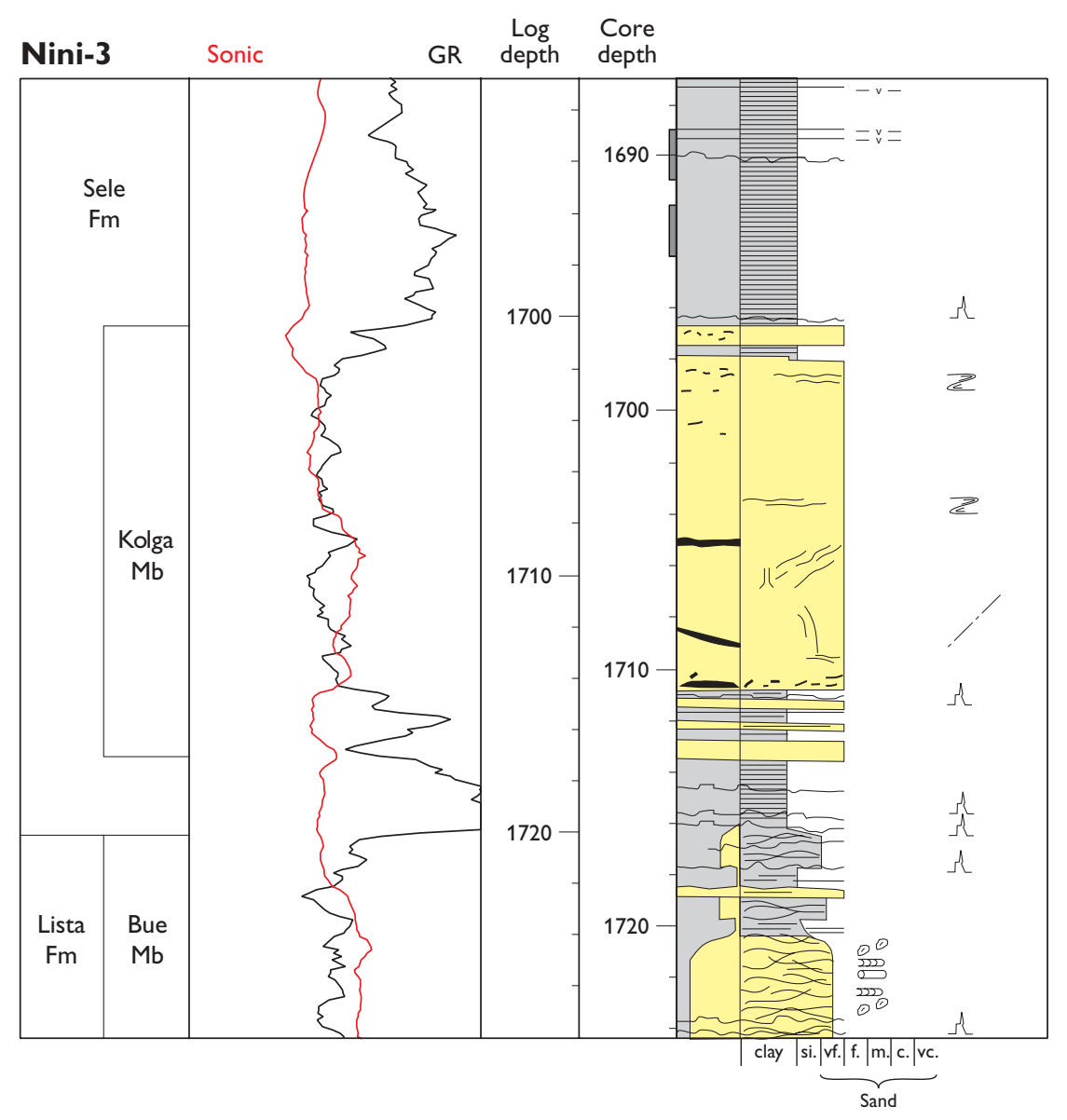

Correlation. The Kolga Member is contemporaneous with parts of the Sele Formation onshore Denmark. It possibly correlates with the Forties Sandstone Member (Knox \& Holloway 1992) in the Central Graben and with the Teal and Skadan Sandstone Members (Knox \& Holloway 1992) in the southern Viking Graben. However, the Kolga Member is not contiguous with those units and has another source area.

\section{Fur Formation}

History. The Fur Formation is a marine diatomite with numerous ash layers. It was formally established by Pedersen \& Surlyk (1983) with a type section in the coastal cliff Knudeklint on the island of Fur, Denmark. Its lower boundary was revised by Heilmann-Clausen et al. (1985). The characteristic lithology of the Fur Formation was subsequently recognised by Thomsen \& Danielsen (1995; Danielsen \& Thomsen 1997) in cuttings samples from three offshore wells located in the north-eastern part of the Danish sector of the North Sea, as well as in one well in the Norwegian sector.

Age. Sparnacian (sensu Aubry et al. 2003) possibly including the latest Thanetian. 


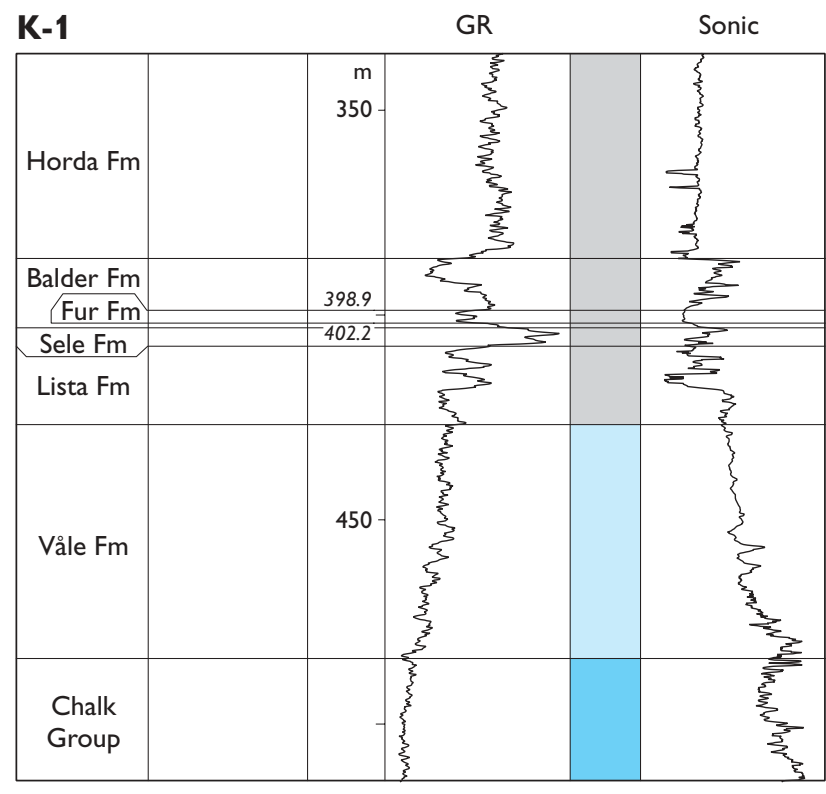

Fig. 40. K-1, reference well for the Fur Formation.

Type section. The coastal cliff Knudeklint, the island of Fur, onshore Denmark (for location map, see Pedersen \& Surlyk 1983).

Reference sections. Silstrup south cliff, Skarrehage, Feggeklit, Harhøj, Stolleklint (for location maps, see Pedersen \& Surlyk 1983).

Danish reference wells. Danish sector wells K-1, 402.2398.9 m MDKB (Fig. 40; Plate 5); Inez-1, 810.7-795.3 m MDKB (Fig. 41; Plates 1, 5).

Distribution and thickness. Onshore Denmark, the Fur Formation is distributed in a limited area in north-west Jutland. It is $c .61 \mathrm{~m}$ thick in its type section. Offshore, the formation occurs in a belt stretching from the northwestern coast of Jutland, continuing into the Norwegian sector parallel to the southern coast of Norway (Thomsen \& Danielsen 1995 text-fig. 6; Fig. 42). It reaches a thickness of $15.4 \mathrm{~m}$ in the Inez-1 well, $7.9 \mathrm{~m}$ in the C-1 well and $3.3 \mathrm{~m}$ in the K-1 well (Figs 40-42).

Lithology. The lithology of the Fur Formation was described from its onshore exposures by Pedersen (1981) and Pedersen \& Surlyk (1983). It is a clayey, porous, dark grey diatomite with numerous volcanic ash layers. Diatom frustules constitute $65 \mathrm{wt} \%$ of the rock, clay particles constitute $35 \mathrm{wt} \%$ (Pedersen 1981). Tests of Coscinodiscus spp. and Stephanopyxis are the major constituent of the diatomite fraction (Thomsen \& Danielsen 1995). Fine lamination is the primary sedimentary structure, but at some

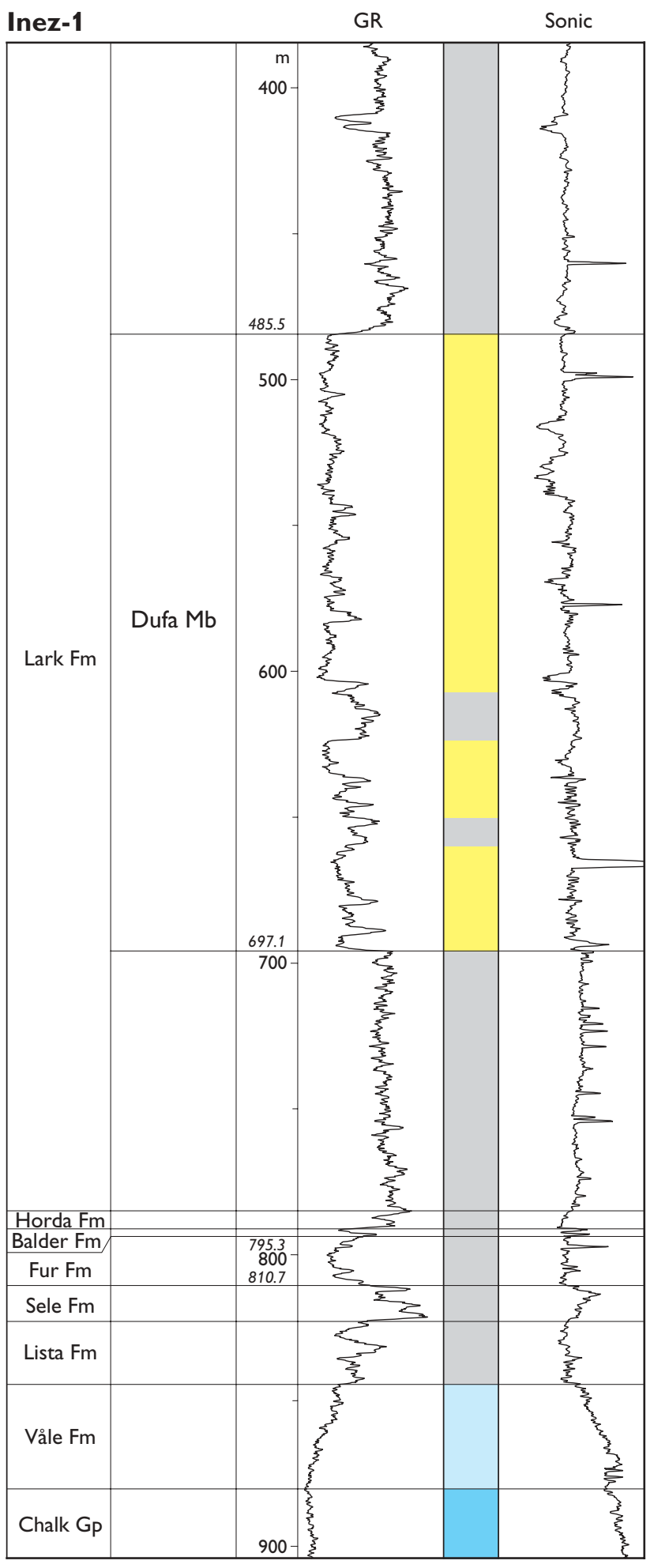

Fig. 41. Inez-1, reference well for the Fur Formation and type well for the Dufa Member. 
levels the lamination has been destroyed by bioturbation. The ash layers are black, graded and consist of volcanic glass particles. Individual layers range from $1-20 \mathrm{~cm}$ in thickness but are fairly uniform in thickness over a limited area (Pedersen $\&$ Surlyk 1983). The diatomite recognised in cuttings samples from North Sea wells by Thomsen \& Danielsen (1995) is a similar lithology to that of the onshore sections studied by Pedersen (1981) and Pedersen \& Surlyk (1983).

Log characteristics. The Fur Formation is identified by the combination of a low gamma-ray response and low sonic readings within an interval of higher sonic readings characterising mudstones below and above (Thomsen \& Danielsen 1995; Danielsen \& Thomsen 1997; Figs 40, 41; Plates 1, 5).

Boundaries. In the C-1 and K-1 wells, the Fur Formation is enveloped by the Balder Formation. In Inez-1, the formation is bounded by the Sele and Balder Formations (Figs 40, 41; Plates 1, 5). It should be noted, however, that Thomsen \& Danielsen (1995 text-fig. 4) and Danielsen \& Thomsen (1997 fig. 5) placed the Fur Formation entirely within the Sele Formation in the K-1 well. The discrepancy between the interpretation herein and that of the former authors is due to different interpretations of the position of the Balder-Sele boundary in the well. The boundary of the Fur Formation with the Balder and Sele Formations is characterised by a change from laminated or structureless diatomite with ash layers to the dark mudstones of the Balder and Sele Formations. This lithological change is reflected on the sonic log by an abrupt increase in velocity (Figs 40, 41; Plates 1, 5).

Subdivision. Onshore Denmark, the Fur Formation is divided into the lower, laminated Knudeklint Member that contains relatively few, widely spaced ash layers and the upper, mainly structureless Silstrup Member with numerous ash layers (Pedersen \& Surlyk 1983).

Macro-andichnofossils. The macrofossil assemblage described from onshore exposures of the Fur Formation encompasses fish, birds, turtles, snakes, starfish, shellfish, snails, mussels, crabs, pteropods, insects, fossil wood, leaves and fructifications (Bonde 1966, 1979, 1987, 2003; Pedersen 1981; Pedersen \& Surlyk 1983; Kristoffersen 2001). Ichnofossils from onshore exposures include Planolites ispp., Teichichnus ispp., Chondrites ispp. and Taenidium ispp. (Pedersen \& Surlyk 1983).

Microfossils and palynomorphs. Diatom frustules are rockforming in the Fur Formation (Pedersen 1981). Silico-

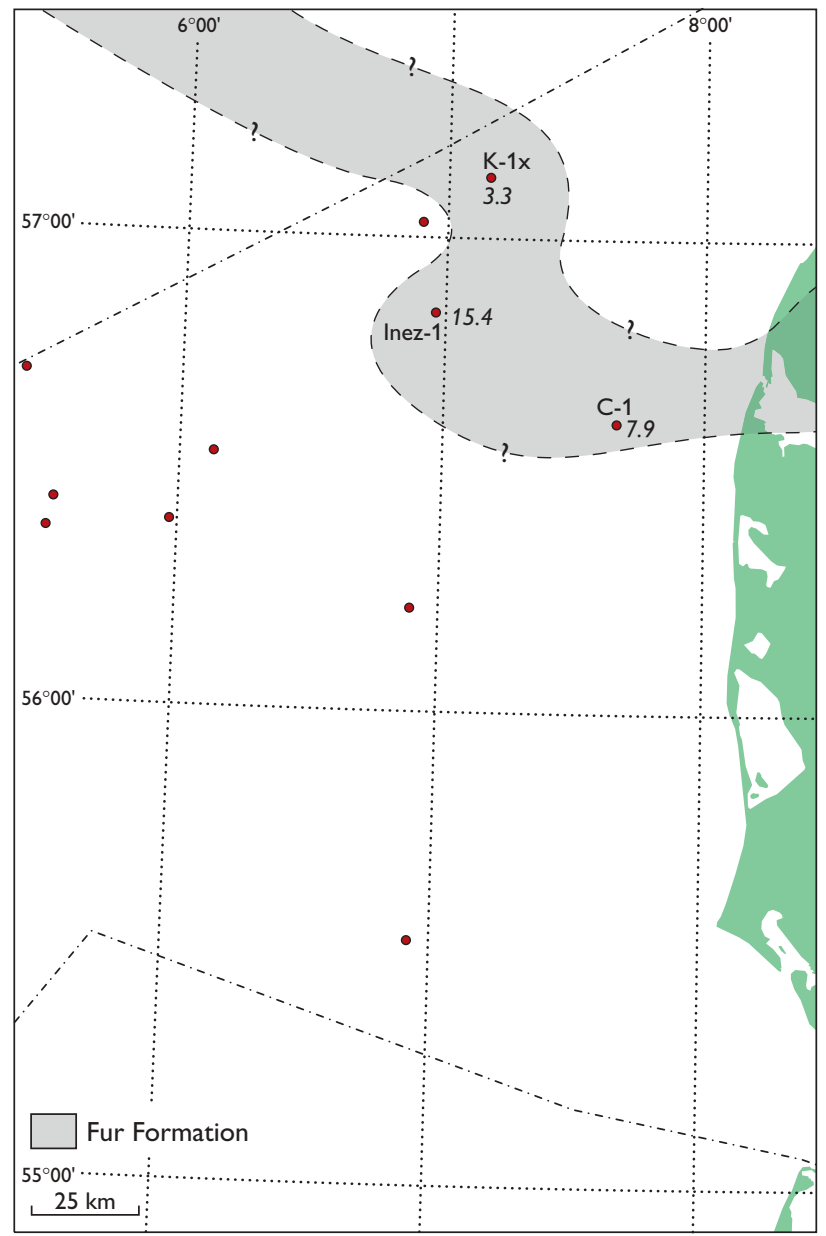

Fig. 42. Distribution map of the Fur Formation with formation thickness $(\mathrm{m})$ indicated for three wells.

flagellates are present (Perch-Nielsen 1976) whereas calcareous microfossils are absent. The formation contains abundant dinoflagellates and sporomorphs (Hansen 1979; Heilmann-Clausen 1982; Willumsen 2004).

Depositional environment. The deposition of the Fur Formation diatomites took place in a long, narrow zone under upwelling conditions (Bonde 1974, 1979). The upwelling was controlled by northerly winds (Bonde 1974, 1979) or it may have been created by a combination of bottom currents and bottom topography (Pedersen \& Surlyk 1983).

Age. Early Ypresian.

Correlation. Onshore Denmark, the Knudeklint and Silstrup Members are largely contemporaneous with the upper part of the Haslund Member and the overlying Værum Member of the Ølst Formation (HeilmannClausen et al. 1985), respectively, and correlate with the 


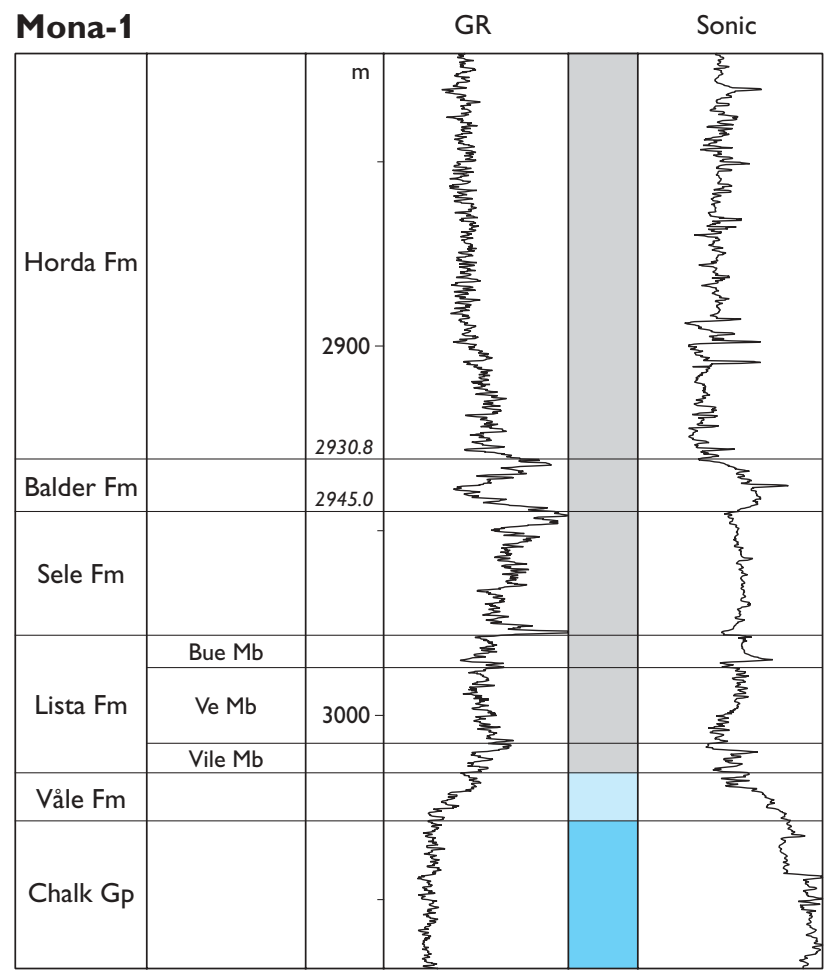

Fig. 43. Mona-1, Danish reference well for the Balder Formation.

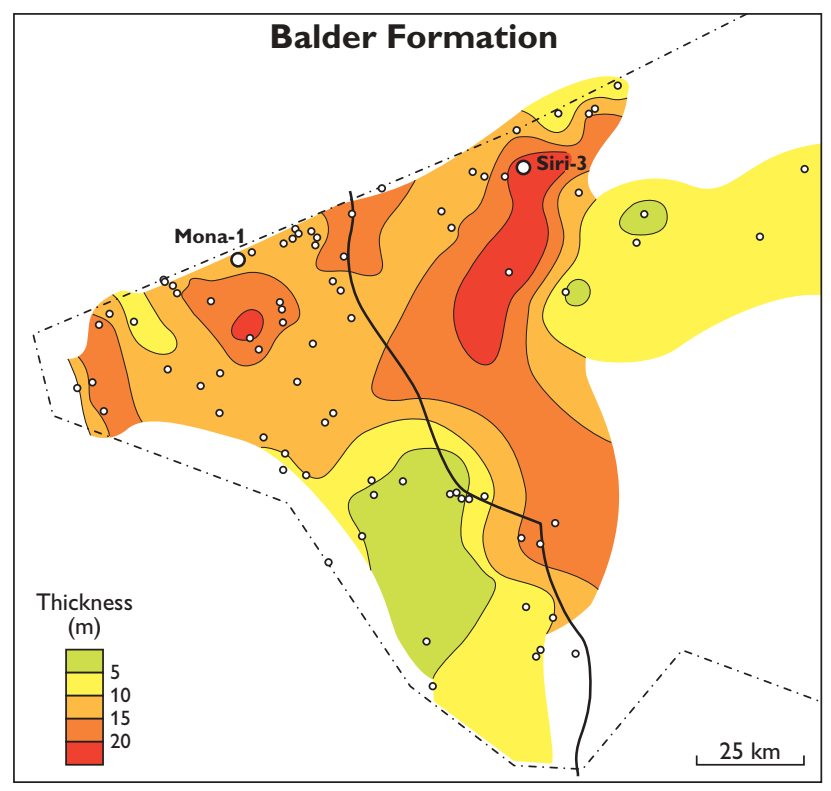

Fig. 44. Isochore map of the Balder Formation in the study area. The positions of the two Danish reference wells, Mona-1 and Siri-3, are indicated in the figure. upper part of the Sele Formation and the lower unit B1 (see below) of the Balder Formation (Heilmann-Clausen 1995; Knox 1997 fig. 3).

\section{Balder Formation}

History. Deegan \& Scull (1977) established the Balder Formation for the succession of variegated, fissile and laminated shales with interbedded tuff layers that lie between the Sele and Horda Formations.

Type well. Norwegian sector well 25/11-1, 1780-1705 m MDKB.

Danish reference wells. Mona-1, 2945.0-2930.8 m MDKB (Fig. 43; Plate 1). Siri-3, 2016.8-1998.8 m MDRT (Fig. 24; Plate 4).

Distribution and thickness. The Balder Formation extends over most of the central and northern North Sea. In the Danish sector, it reaches a thickness of more than $20 \mathrm{~m}$ in the Siri-3 and Frida-1 wells on the western part of the Ringkøbing-Fyn High (Fig. 1) and $20 \mathrm{~m}$ in Gwen-2 in the northern part of the Danish sector of the Central Graben. The Balder Formation thins to less than $5 \mathrm{~m}$ towards the south-west and to less than $10 \mathrm{~m}$ in the eastern part of the Danish sector of the North Sea. The Balder Formation is lacking in the Danish well S-1 (Michelsen et al. 1998). An isochore map of the Balder Formation is shown in Fig. 44.

Lithology. The Balder Formation is composed of laminated, dominantly grey, fissile shales with interbedded dark and light grey, purple, buff and green sandy tuffs (Fig. 45). The tuffs are normally graded and less than $5 \mathrm{~cm}$ thick. Locally the tuff beds are slumped. The tuff layers may be cut by irregular, vertical, calcite-filled cracks up to $20 \mathrm{~cm}$ long (Fig. 45). Similar cracks have been reported from the Balder Formation in the Grane Field, Norwegian sector of the North Sea (Haaland et al. 2000). Sandstone beds, interpreted as intrusive sandstone bodies, occur locally in the Balder Formation.

Log characteristics. The Balder Formation is characterised by a relatively high gamma-ray values in its lower and higher parts, but shows low values in its middle part. The change in gamma-ray response is normally gradual, but relatively steep. The gamma-ray motif is mirrored by a gradual increase in sonic readings commencing at the formation base, culminating at or slightly below the level of minimum gamma-ray values in the middle part of the 
formation, followed by a gradual decrease towards the top of the formation where the lowest sonic reading is reached. The gamma and sonic motifs together create a characteristic barrel-shaped log pattern (e.g. Figs 24, 33, 38, 43; Plates 1-5).

Boundaries. In general, the boundary with the underlying Sele Formation is gradational, although it can be sharp in some wells. Where gradational, it is placed where the tuff layers become prominent (e.g. Fig. 45). On petrophysical logs, the lower boundary is identified at a significant upward decrease in gamma-ray response accompanied by an increase in sonic readings (e.g. Figs 24, 33, 38, 43). The upper boundary is at the base of the Horda Formation.

Subdivision. Knox \& Holloway (1992) subdivided the Balder Formation into a lower, laminated and tuff-rich unit (B1) and a poorly laminated upper unit (B2). This subdivision can be recognised in a number of Danish wells west of Cecilie-1, but the B2 unit seems to be absent from Danish North Sea wells north-east of, and including, the Cecilie-1 well.

Macro- and ichnofossils. Macrofossils have not been observed. The Balder Formation is non-bioturbated to moderately bioturbated. Ichnofossils comprise Chondrites ispp., Phycosiphon ispp., Planolites ispp. and Thalassinoides ispp.

Microfossils and palynomorphs. The Sele-Balder boundary interval is characterised by the $\mathrm{HO}$ of common Fenestrella antiqua and Coscinodiscus morsianus (both diatoms). This event is located in the uppermost part of the Sele Formation but may be used as a biostratigraphic guide to locate the boundary. The diatom Fenestrella antiqua characterises the Balder Formation and has its $\mathrm{HO}$ at the formation top. The dinoflagellate Deflandrea oebisfeldensis shows an acme at the top of the Balder Formation. As observed in the underlying Sele Formation, the Balder Formation contains high numbers of spores and pollen, in particular pollen of the genus Inaperturopollenites spp., and the top of the Balder Formation is marked by the $\mathrm{HO}$ of common representatives of that genus. In contrast to the overlying Horda Formation, calcareous benthic foraminifers are virtually absent in the Balder Formation.

Depositional environment. A restricted marine palaeoenvironment at upper bathyal depths with dysoxic to anoxic bottom conditions is suggested for the Balder Formation. This is based on the scarcity of calcareous microfossils and agglutinated foraminifers combined with common to abundant siliceous microfossils, especially diatoms. The

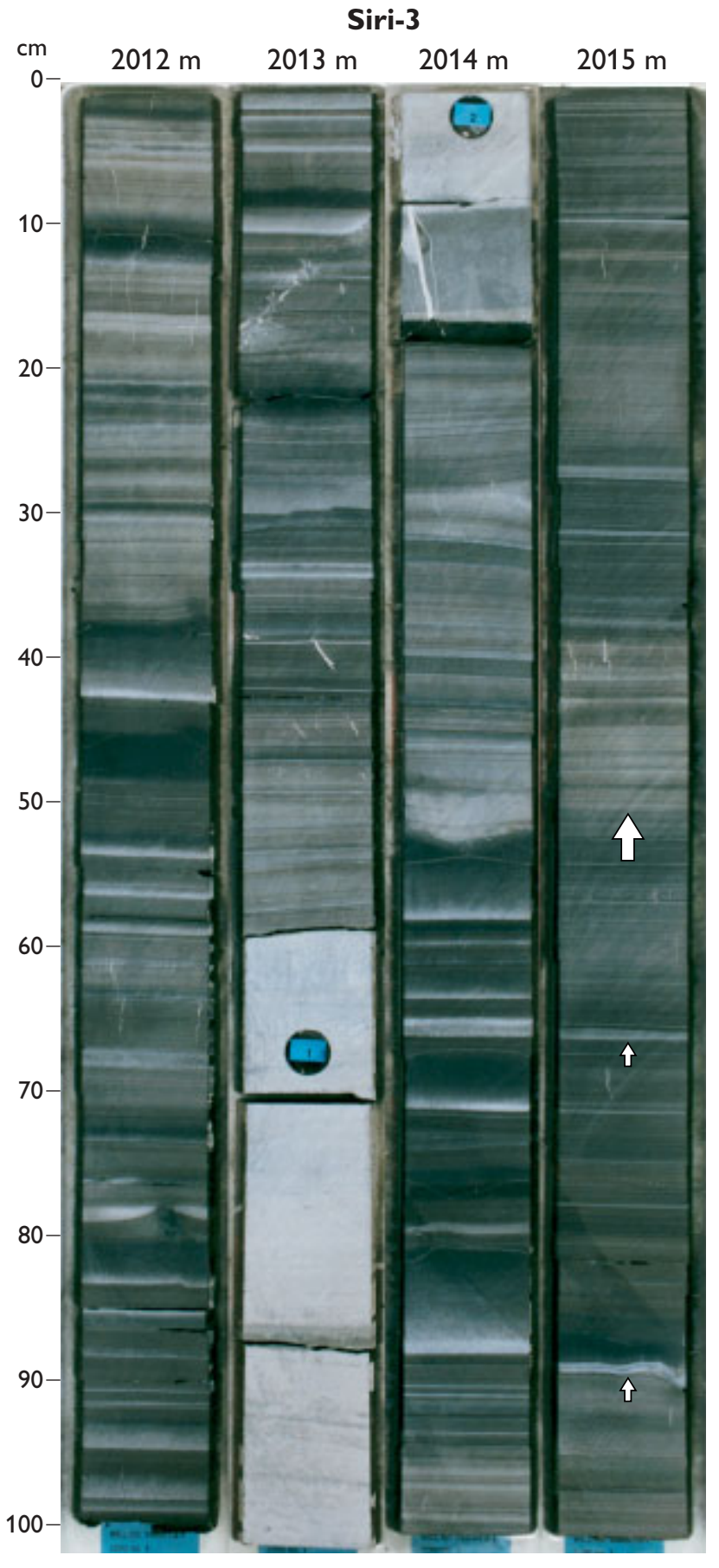

Fig. 45. Core photographs of tuffaceous Balder Formation mudstones from the Siri-3 well. The tuff layers are seen as light coloured, graded intervals (e.g. at 2012.42-2012.40 m). The boundary with the underlying Sele Formation is placed where tuffs become common, at 2015.5 $\mathrm{m}$ (large arrow); two tuff layers may be seen in the uppermost Sele Formation, at 2015.66 and $2015.90 \mathrm{~m}$ (small arrows). Two small, lightning-shaped cracks are seen at $2015.4 \mathrm{~m}$. Depths are core depths. 
Mona-1

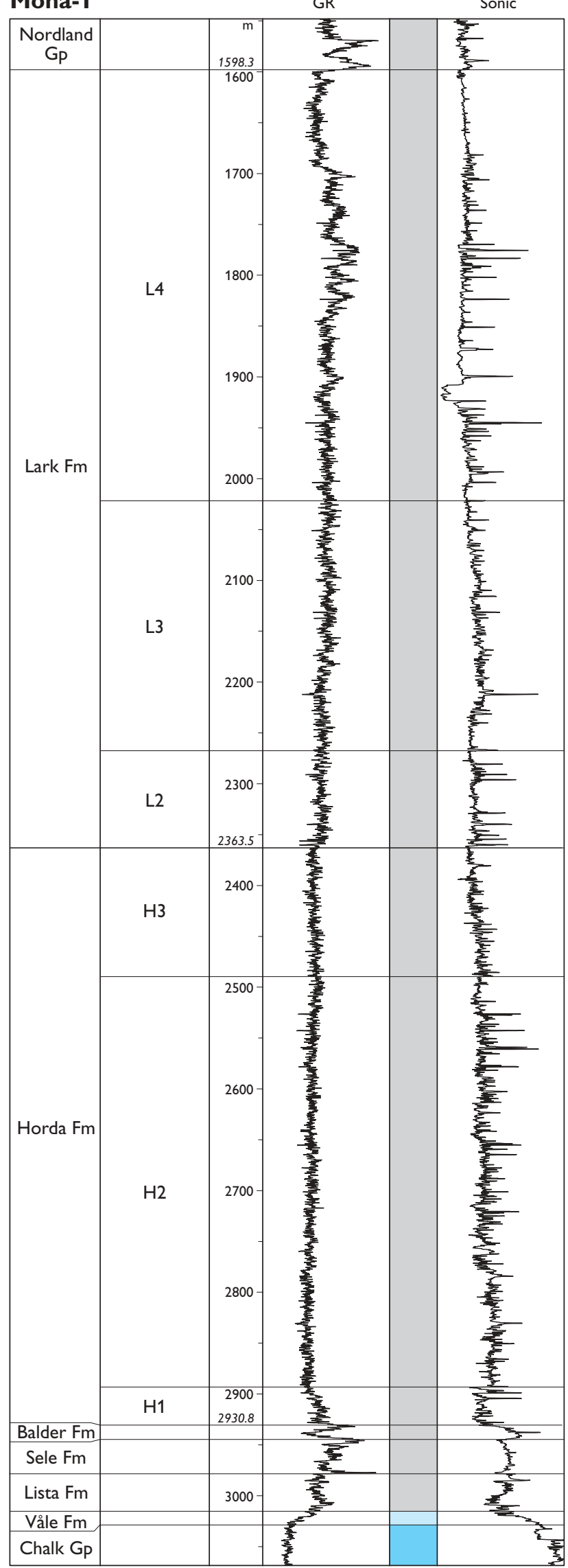

presence of abundant terrestrial palynomorphs further supports a restricted, marginal marine depositional setting.

A petrographic and geochemical study of the Balder Formation in the Grane Field, Norwegian North Sea sector, shows that the tuffs can be classified as representing sub-alkaline basalts and basaltic andesites of intra-plate origin (Haaland et al. 2000). The tuffs are similar to the contemporaneous Lower Basalts in East Greenland, the Rockall Trough and the Middle Series of the Faeroe Islands, all linked to the opening of the North Atlantic (Haaland et al. 2000). The volcanic phase took place at 55-52 Ma.

\section{Age. Early Ypresian.}

Correlation. Although unit B2 of Knox \& Holloway (1992) is apparently lacking in wells in the north-eastern part of the Danish sector, both units B1 and B2 can be correlated with strata onshore Denmark, although unit B2 is very thin. Unit B1 corresponds to the lithologically similar Værum Member of the widespread Ølst Formation onshore Denmark and with the diatomaceous Silstrup Member of the Fur Formation in north-west Jylland (Knox 1997 fig. 3). The lower boundary of the Værum and Silstrup Members is placed at ash layer no. +1 in the tephrachronology of Bøggild (1918). The ash chronology has not been identified in the type section of the Balder Formation and precise correlation with the lower boundary of the Værum and Silstrup members is therefore uncertain. However, judging from the abundance of thick ash layers in the Balder Formation and the scarcity of ash layers in the underlying Sele Formation, it is likely that the base of the Balder Formation approximately correlates with ash layer no. +1 , i.e. with the base of the Værum and Silstrup Members.

According to Knox (1997 fig. 3), unit B2 probably correlates with the Knudshoved Member of the Røsnæs Clay Formation (Heilmann-Clausen et al. 1985). This member has a very restricted distribution in north-west Jylland where it overlies the Silstrup Member of the Fur Formation. The Knudshoved Member consists of a lower dark grey, pyritic clay unit rich in pyritised diatoms, and an upper greenish clay unit (Heilmann-Clausen et al. 1985). Only a few, thin volcanic ash layers are present in the member (Håkansson \& Sjørring 1982). Based on lithological comparison, it is suggested that at least the lower,

Fig. 46. Mona-1, Danish reference well for the Horda and Lark Formations. The figure shows the tripartite subdivision of the Horda Formation and the L2-4 units of the Lark Formation. The L1 unit is absent in the Mona-1 area. 


\section{Siri-1}

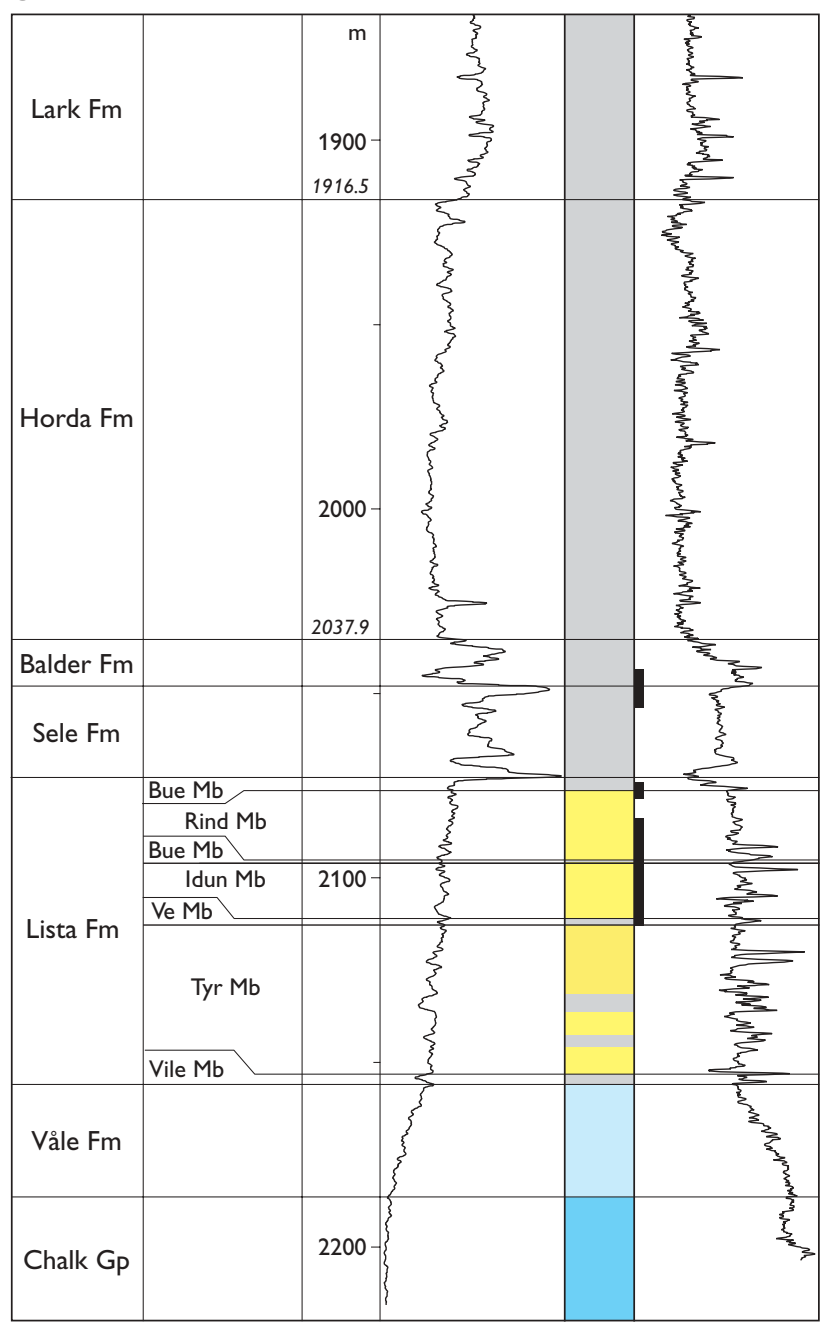

Fig. 47. Siri-1, Danish reference well for the Horda Formation. Black bars show cored sections.

pyritic part of the Knudshoved Member may correlate with the upper, tuff-poor unit B2 of the Balder Formation.

\section{Stronsay Group}

Knox \& Holloway (1992) replaced the Hordaland Group of Deegan \& Scull (1977) with two new groups: the Stronsay Group succeeded by the Westray Group (Fig. 3). The two groups together comprise the light grey, green and brown coloured, soft, fissile, marine shales with thin limestone streaks that overlie the Rogaland Group and underlie the Nordland Group. These groups each contain two formations, one representing sandy shelf lithofacies and the other representing basinal mudstone lithofacies. In the central North Sea, and in the Danish sector, the Stronsay Group is represented by its mudstone facies, the Horda

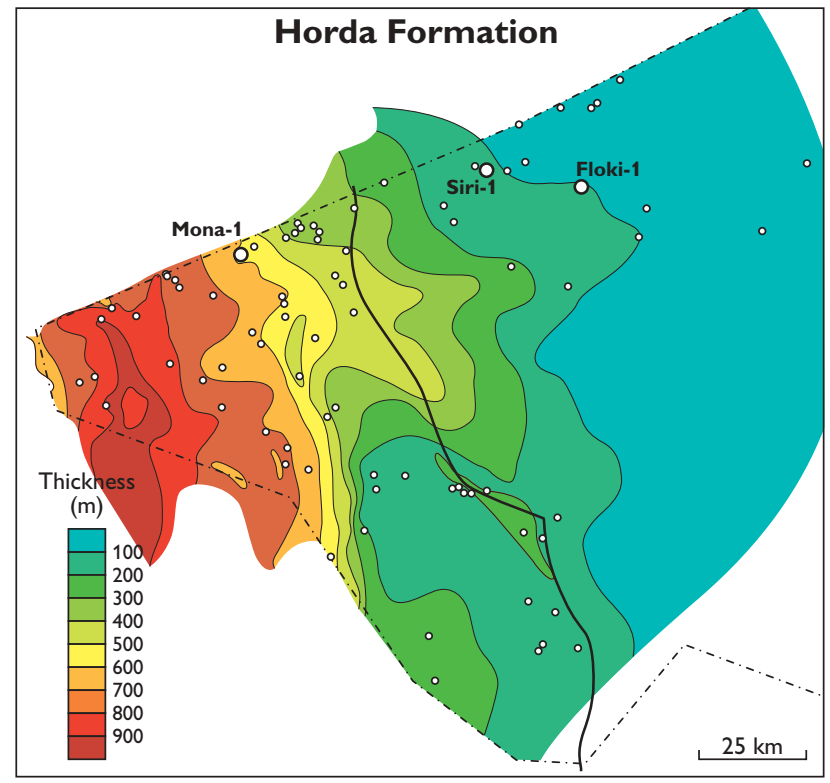

Fig. 48. Isochore map of the Horda Formation in the study area. The positions of the two Danish reference wells for the Horda Formation, Mona- 1 and Siri-1, are indicated on the map. The position of Floki-1, the type well for the Hefring Member, is also indicated.

Formation (Knox \& Holloway 1992). Sandstone units of varying thickness occur at many levels in the Stronsay and Westray Groups along the basin margin in the Norwegian and British sectors, and many of these have been defined as formations or members (Deegan \& Scull 1977; Hardt et al. 1989; Knox \& Holloway 1992). A sandstone unit also occurs in the Horda Formation on the Ringkøbing-Fyn High in the Danish sector and is described here as a new member (Hefring Member).

\section{Horda Formation}

History. Knox \& Holloway (1992) established the Horda Formation for the greenish grey basinal mudstone facies of their Stronsay Group that overlies the grey tuffaceous mudstones of the Balder Formation and underlies the greenish grey to brown mudstones of the Lark Formation (Knox \& Holloway 1992).

Type well. British sector well 22/1-1A, 2379.5-1992 m MDKB.

Danish reference wells. Mona-1, 2930.8-2363.5 m MDKB (Fig. 46); Siri-1, 2037.9-1916.5 m MDKB (Fig. 47).

Distribution and thickness. The Horda Formation extends over the central and northern North Sea and is present in 